\title{
PERAN SATUAN PERLINDUNGAN MASYARAKAT DI KABUPATEN CILACAP
}

\section{ROLE OF SOCIAL PROTECTION UNIT DISTRICT CILACAP}

\author{
Gunawan \\ Pusat Penelitian Pemerintahan Umum dan Kependudukan \\ Badan Penelitian dan Pengembangan (BPP) Kementerian Dalam Negeri \\ Jl. Kramat Raya No. 132 - Senen, Jakarta \\ Telp. 0213140454 HP. $081288140777 ; 0877888877866$ \\ e-mail: wawangunawan678@gmail.com
}

Dikirim: 13 Juni 2014 Direvisi: 20 Agustus 2015 Disetujui: 20 Oktober 2015

\begin{abstract}
Abstrak
Penyelenggaraan keamanan dan ketentraman, ketertiban serta perlindungan masyarakat khususnya yang berada dilingkungan permukiman merupakan tugas dan tanggung jawab anggota satuan perlindungan masyarakat (satlinmas), dan bagaimana yang terjadi bila anggota satlinmas dalam melaksanakan tugas dan fungsinya tidak didukung dengan sumber daya manusia yang memadai baik kualitas maupun kuantitasnya, sehingga harapan dan keinginan masyarakat untuk mendapatkan keamanan dan ketentraman, ketertiban serta perlindungan masyarakat tidak terpenuhi dengan sepenuhnya dan mengakibatkan kehadiran satlinmas belum dapat dirasakan manfaatnya oleh masyarakat. Metode yang digunakan dalam penelitian ini menggunakan penelitian kualitatif dengan analisis deskriptif, data diperoleh melalui dokumentasi, observasi, dan wawancara, lokasi sampel penelitian dipilih berdasarkan purposive sampel yaitu Kabupaten Cilacap, Kabupaten Cilacap merupakan kabupaten yang telah mengakomodir kelembagaan Linmas dalam struktur organisasi Satuan Polisi Pamong Praja dan menjadi barometer bagi daerah lain dalam pelaksanaan penegakan peraturan daerah. Tujuan kajian ingin mengetahui sejauhmana Satlinmas dapat berperan sesuai dengan tugas dan fungsinya. Hasil penelitiannya bahwa peran Satlinmas dalam menyelenggarakan penanganan kebencanaan, penanganan keamanan, ketenteraman dan ketertiban, perlindungan masyarakat di tingkat kabupaten pada umumnya sudah dapat dilaksanakannya, namun pada tingkat rukun tetangga dan rukun warga tugas dan fungsi tersebut belum dapat dilaksanakan dengan optimal.
\end{abstract}

Kata kunci: Satlinmas, Peran, Tugas, Fungsi.

\begin{abstract}
Implementation of security and peace, order and protection of the people especially those who are within the settlement is the duty and responsibility of member units of community protection (Satlinmas), and what happens when members Satlinmas in carrying out its duties and functions not supported by the human resources of adequate quality and quantity, so the expectations and desires of the community to get security and peace, order and public protection are not met in full and result in (Satlinmas) presence can not be felt by the community. The method used in this study using qualitative research with descriptive analysis, the data obtained through documentation, observation, and interviews, sample locations were selected based on purposive sample of Cilacap, Cilacap is a district that has accommodated the institutional Linmas the organizational structure of Civil Service Police Unit and a barometer for other regions in the implementation of the enforcement of local regulations. The purpose of the study wanted to know how far Satlinmas can act in accordance with its duties and functions. Research results that Satlinmas role in organizing disaster management, the handling of security, peace and order, protection of the public at the district level are generally already be implemented, but at the neighborhood level and harmonious citizens tasks and functions are yet to be implemented optimally.
\end{abstract}

Keywords: Satlinmas, Role, Duties, Functions.

\section{PENDAHULUAN}

Satuan Perlindungan Masyarakat (Satlinmas) merupakan kumpulan sekelompok orang yang dibekali dengan pengetahuan dan keterampilan guna dapat melaksanakan tugas dan fungsinya dalam penanganan bencana, menjaga keamanan, ketenteraman, dan ketertiban serta dapat berperan aktif dalam kegiatan sosial kemasyarakatan. Tentang terbentuknya Satlinmas itu sendiri, mengalami perjalanan sejarah yang cukup panjang sampai sekarang ini, sebelum terbentuknya Satlinmas dahulu sering juga disebut dengan Pertahanan Sipil (Hansip). 
Awal dibentuknya organisasi Hansip ini dimulai sejak pemerintahan Hindia Belanda untuk menghadapi serangan dari Jepang. Pemerintah Belanda membentuk suatu organisasi yang bertugas untuk melindungi masyarakat dari serangan udara musuh. Waktu itu dikenal dengan LBD (Lucht Bescherming Dients) atau Perlindungan Pemecah Udara. LBD ini dibentuk dari tingkat pusat sampai daerah yang dikoordinasikan oleh pejabat-pejabat pemerintahan sipil. Kegiatannya meliputi penerangan masyarakat, pemberitaan serangan udara musuh, perlindungan, penyamaran, pemadam kebakaran, pertolongan pertama pada penderita kecelakaan, pengungsian dan lain-lain.

Setelah jaman pendudukan Jepang, Pemerintah Jepang membentuk organisasi semacam LBD yang disebut Pertahanan Sipil pada 1943 yang waktu itu diarahkan kepada pertahanan dan untuk pengerahan rakyat total. Organisasi tersebut dibentuk sampai di lingkungan masyarakat terkecil dalam bentuk gumi atau yang sekarang dikenal sebagai RT. Organisasi inilah yang menjadi cikal bakal hansip yang dirangkaikan dengan kepentingan pertahanan dan perlindungan masyarakat terhadap serangan musuh. Selain itu, Hansip juga dibebani dalam hal penjagaan keamanan, pengumpulan dana, pengaturan bahan makanan dan lain-lain.

Selanjutnya setelah zaman kemerdekaan, lahirlah Keputusan Wakil Menteri Pertama Urusan Pertahanan/Keamanan No MI/A/72/62 tanggal 19 April Tahun 1962 Tentang Peraturan Pertahanan Sipil, sampai dengan 1972. Lalu, ketika pembinaan hansip diserahkan dari Menteri Pertahanan Keamanan/Panglima Angkatan Bersenjata kepada Menteri Dalam Negeri dikukuhkan dengan ${ }^{1}$ Keppres No 55 Tahun 1972. Bersamaan dengan Keppres No 55 Tahun 1972, telah ada pula Keppres Nomor 56 Tahun 1972 tentang Penyempurnaan Organisasi Pertahanan Sipil dan Organisasi Perlawanan Rakyat (Wanra) dan Keamanan Rakyat (Kamra) dalam rangka penertiban pelaksanaan sistem pertahanan keamanan rakyat.

Ketika hansip diserahkan kepada Departemen Dalam Negeri pada intinya masih berkisar pada pertahanan, dan keamanan, hansip ditugaskan untuk memobilisasi rakyat untuk kegiatan pertahanan negara, memobilasi aktivitas masyarakat sipil dalam pertahanan negara melawan musuh. Namun, dalam perkembangannya setelah masuk dalam pembinaan Departemen Dalam Negeri, satuan pertahannan sipil dalam kehidupannya membantu sosial

\footnotetext{
${ }^{1}$ Keppres No 55 Tahun 1972 tentang Penyempurnaan Organisasi Pertahanan Sipil dan Organisasi Perlawanan Rakyat (Wanra) dan Keamanan Rakyat (Kamra) dalam rangka penertiban pelaksanaan sistem pertahanan keamanan rakyat.
}

kemasyarakatan dalam bentuk pengamanan lingkungan.

Tugas-tugas hansip dalam sosial kemasyarakatan adalah membina ketertiban masyarakat sosial masyarakat, membantu masyarakat ketika ada kegiatan-kegiatan sosial seperti kematian, hajatan, upacara dan keagamaan. Sampai pembentukan dapur umum di desa atau kelurahan ketika ada bencana. hansip ini tidak pernah menjalani latihan dasar militer (latsarmil) dan belum mendapat arahan yang tepat dari Departemen Dalam Negeri selaku pembina hansip.

Baru pada 2002, Hansip kemudian berubah nama menjadi Perlindungan Masyarakat (Linmas) hingga saat ini. Meski begitu, perubahan itu hanya pada label namanya saja, landasan hukum tentang tugas pokok, fungsi, dan perannya masih tetap sama. Sebagai gambaran tugas pokok hansip ketika dinaungi Departemen Pertahanan Keamanan meliputi pertahanan kemanan sedangkan dalam Linmas dimaknai sebagai suatu fungsi dalam memberikan perlindungan kepada masyarakat.

Fungsi memberikan perlindungan masyarakat merupakan kegiatan yang harus dilaksanakan oleh Linmas, dengan demikian pembinaan terhadap Linmas sejak 2004 dilaksanakan oleh pemerintah daerah di bawah Satuan Polisi Pamong Praja (Satpol PP). Ini sesuai dengan isi dari Undang-Undang No 23 Tahun 2014 Tentang Pemerintahan Daerah yang menyatakan urusan wajib menjadi kewenangan pemerintah provinsi, kabupaten/kota, meliputi penyelenggaraan ketertiban umum dan ketentraman masyarakat termasuk di dalamnya perlindungan masyarakat.

Sejalan dengan beriringnya waktu Undang Undang No 32 Tahun 2004Tentang Pemerintahan Daerah dengan Keputusan Presiden No 55 Tahun 1972 Tentang Penyempurnaan Organisasi Pertahanan Sipil dan Organisasi Perlawanan Rakyat (Wanra) dan Keamanan Rakyat (Kamra) dalam rangka penertiban pelaksanaan sistem pertahanan keamanan rakyat dirasakan sudah tidak sesuai, sementara Undang-Undang No 32 Tahun 2004 Tentang Pemerintahan Daerah lebih menekankan pada perlindungan dan ketertiban masyarakat. Untuk itu, Kementerian Dalam Negeri mengajukan permohonan kepada presiden untuk mencabut Keputusan Presiden tersebut melalui melalui Peraturan Presiden No 88 Tahun 2014 Tentang Pencanbutan Keputusan Presiden Nomor 55 Tahun 1972 Penyempurnaan Organisasi Pertanahan Sipil dan Organisasi Perlawanan Rakyat (Wanra) dan Keamanan Rakyat (Kamra) dalam rangka penertiban pelaksanaan sistem pertahanan keamanan rakyat supaya Linmas bisa dikembangkan lebih lanjut.

Kemudian sampailah kepada diterbitkannya Peraturan Presiden No. 88 Tahun 2014 tentang pencabutan Keputusan Presiden No. 55 Tahun 1972 tentang Penyempurnaan Organisasi Pertanahan Sipil dan Organisasi Perlawanan Rakyat (Wanra) dan 
Keamanan Rakyat (Kamra) dalam rangka penertiban pelaksanaan sistem pertahanan keamanan rakyat, mulai saat itu terdapat kekosongan peraturan tentang perlindungan masyarakat maupun pertahanan sipil, dengan dicabutnya Keputusan Presiden No. 55 Tahun 1972, merupakan momen yang tepat untuk segera menata ulang satuan perlindungan masyarakat agar keberadaannya lebih berkembang dan dapat dirasakan manfaatnya oleh masyarakat.

Penataan ulang Satuan Perlindungan Masyarakat (Satlinmas) sebaiknya dimulai dari regulasinya terlebih dahulu, didalam Undang Undang 23 Tahun 2014 tentang Pemerintahan Daerah dan peraturan lainnya terdapat 7 peraturan yang mendefinisikan peran Satlinmas menggunakan kata keamanan, sedangkan peran keamanan merupakan urusan wajib pemerintah secara absolut yang tertuang

Undang-undang 23 Tahun 2014 Tentang Pemerintahan Daerah Pasal 10 Ayat 1 menyebutkan bahwa terdapat 6 (enam) urusan pemerintahan secara absolut yang menjadi kewenangan pemerintah pusat yang terdiri dari: 1) politik luar negeri; 2) pertahanan; 3) keamanan; 4) yustisi; 5) moneter dan fiskal nasional; serta yang terakhir adalah urusan 6) agama.

Keenam (6) urusan absolut itulah yang menjadi kewenangan pemerintah pusat untuk dilaksanakan dan tidak dapat digangu gugat, sedangkan pemerintah daerah diberi kewenangan untuk mengurus yang berkaitan dengan urusan wajib dan urusan pilihan. Sesuai dengan Undang-undang 23 Tahun 2014 Tentang Pemerintahan Daerah Pasal 12 Ayat 1 urusan pemerintahan wajib yang berkaitan dengan pelayanan dasar sebagaimana dimaksud dalam Pasal 11 ayat (2) meliputi: 1) pendidikan; 2) kesehatan; 3) pekerjaan umum dan penataan ruang; 4) perumahan rakyat dan kawasan permukiman; 5) ketenteraman, ketertiban umum, dan pelindungan masyarakat; dan 6) Sosial.

Sebagaimana diketahui masih banyak peraturan-peraturan yang mendifinisikan Satuan Perlindungan Masyarakat seperti didalam Peraturan Menteri Dalam Negeri Nomor 10 Tahun 2009 Tentang Penugasan Satlinmas dalam Penanganan Ketenteraman, Ketertiban, dan Keamanan Penyelenggaraan Pemilihan Umum, kata keamanan tertuang dalam Pasal 1 ayat 1 disebut bahwa Satlnmas adalah warga masyarakat yang disiapkan dan dibekali pengetahuan serta keterampilan untuk melaksanakan kegiatan penanganan bencana guna mengurangi dan memperkecil akibat bencana, serta ikut memelihara keamanan, ketentraman, dan ketertiban masyarakat serta kegiatan sosial kemasyarakatan.

Definisi Satlinmas itu sendiri terdapat kandungan arti tugas-tugas yang merupakan penjabaran dari urusan pelayanan dasar yang menjadi kewenangan dari pemerintah daerah yang dilaksanakan oleh anggota Satlimas, Urusan-urusan tersebut selain terdapat dalam Undang-Undang 23 Tahun 2014 tentang Pemerintahan Daerah, semua urusan yang menjadi kewenangan pemerintah dan pemerintah daerah provinsi, kabupaten/kota, pembagian urusan pemerintahan, bahwa urusan pemerintahan yang menjadi kewenangan Pemerintah meliputi politik luar negeri, pertahanan, keamanan, yustisi, moneter dan fiskal nasional, serta agama, selanjutnya urusan pemerintahan yang dibagi bersama antara tingkatan dan/atau susunan pemerintahan adalah semua urusan pemerintahan di luar urusan pemerintah.

Cukup jelas dari dasar peraturan tersebut, pemerintah daerah tidak boleh mengambil yang menjadi urusan pemerintah seperti dalam bidang keamanan, karena urusan bidang keamanan merupakan menjadi kewenangan dari Kepolisian Negara Republik Indonesia, dengan menjalankan fungsi pemerintahan negara di bidang pemeliharaan keamanan dan ketertiban masyarakat, penegakan hukum, perlindungan, pengayoman, dan pelayanan kepada masyarakat.

Tupoksi yang dilaksanakan dengan kepolisian tersebut jelas tergambarkan bahwa, banyak tugastugas tersebut terdapat kemiripan dengan tugas Satuan Perlindungan Masyarakat, hanya saja penekanannya terdapat pada urusan absolut yang menjadi kewenangan pemerintah pusat, serta urusan pemerintah daerah hanya pada pelayanan dasar kepada masyarakat.

Pemerintah daerah dalam memberikan pelayanan dasarnya kepada masyarakat, didasari dengan Peraturan Menteri Dalam Negeri Nomor 69 Tahun 2012 Tentang Standar Pelayanan Minimal Bidang Pemerintah Dalam Negeri di Kabupaten/Kota. Didalam pesan Peraturan Menteri Dalam Negeri Nomor 69 Tahun 2012 mengamanahkan bahwa yang terkait dengan tupoksi dari satuan perlindungan masyarakat didaerah, menurut jenis pelayanan dasarnya adalah pemeliharaan ketertiban umum, ketenteraman masyarakat dan perlindungan masyarakat, dengan indikator cakupan rasio petugas perlindungan masyarakat (Linmas) di kabupaten/kota dengan nilai satu (1) orang atau anggota satuan perlindungan masyarakat pada setiap rukun tetangga atau sebutan lainnya, target capaian pada Tahun 2014.

Bila capaian indikator rasio satu (1) petugas perlindungan masyarakat disetiap Rukun Tetangga (RT), dapat dipastikan bahwa jumlah sumber daya manusia anggota Satlinmas di Indonesia merupakan jumlah anggota terbesar di Indonesia, berdasarkan data dari Kepala Bidang Satuan Perlindungan Masyarakat Direktorat Jenderal Pemerintahan Umum Kementerian Dalam Negeri dalam acara seminar di Kantor Badan Penelitian dan Pengembangan tanggal 22 Desember 2014, jumlah anggota Satlinmas sebesar 5.300.000 dan yang terdaftar 1.500.000, jumlah tersebut, jika diikuti dengan kemampuan pengetahuan dan keterampilan yang memadai 
merupakan kekuatan yang besar, melebihi jumlah Tentara Nasional Indonesia (TNI) dan Kepolisian Negara Republik Indoenesia (POLRI).

Sebagaimana diketahui TNI memiliki garis komando terendah berada di satuan tingkat kecamatan yaitu Komando Rayon Militer (Koramil) dipimpin oleh seorang Komandan Rayon Militer (Danramil), dan selanjutnya POLRI memiliki garis komando yang terendah berada pada tingkat sektor Kecamatan yaitu Polisi Sektor (Polsek), kedua Unsur aparatur tersebut dalam bentuk unit terbesar sedangkan Aparatu TNI dan POLRI pada tingkat Kelurahan dan desa yaitu Babinsa dan Babinkamtibmas hanya perorang saja, serta Badan Penanganan Bencana Daerah (BPBD) berada pada tingkat Kabupaten dan Kota, sedangkan garis komando Satlinmas terendah sampai kepada tingkat RT dan RW.

Dengan adanya garis komando Satlinmas sampai kepada tingkat RT dan RW, dapat dipastikan maka jumlah anggota Satlinmas akan lebih besar dari TNI dan POLRI serta BPBD, jumlah yang besar itu merupakan kekuatan dan peluang, bila anggota tersebut diberi pengetahuan dan keterampilan untuk dapat melaksanakan penanganan bencana guna mengurangi dan memperkecil akibat bencana, serta ikut memelihara keamanan, ketentraman dan ketertiban masyarakat, kegiatan sosial kemasyarakatan.

Anggota Satlinmas tentunya dapat diberdayakan dan didayagunakan untuk mengisi kekosongan yang tidak dapat dijangkau oleh TNI, POLRI dan BPBD serta Satpol PP secara cepat, tepat dan langsung melayani masyarakat, untuk dapat langsung melayani masyarakat secara cepat dan tepat, diperlukan tenaga yang terampil dan memiliki kemampuan dan pengetahuan dalam melaksanakan tugas-tugasnya, namun dalam kenyataanya masih dijumpai anggota Satlinmas di Kelurahan dan Desa belum memperoleh pengetahuan dan keterampilan yang persiapkan untuk melaksanakan tugas dan fungsinya dalam menangani kebencanaan, keamanan, ketenteraman dan ketertiban serta aktif berperan di masyarakat, dengan minimnya pengetahuan dan keterampilan tentang kelinmasan maka, anggota Satlinmas menjadi ragu untuk melakukan tugas dan fungsinya.

Berdasarkan latar belakang diatas kiranya penelitian ini penting untuk dilakukan, yang dapat digunakan sebagai rumusan kembali peran yang dapat diaplikasikan dan dimanfaatkan oleh masyarakat.

Peran dalam Kamus Besar Bahasa Indonesia ${ }^{2}$ yaitu jabatan (pekerjaan) yang dilakukan, peran merupakan penjabaran dari tugas dan fungsi, berbicara tentang peran maka yang akan dibahas adalah seputar tugas dan fungsi, karena peran dan

\footnotetext{
${ }^{2}$ http://kbbi.web.id/fungsi diunduh tanggal 24 Oktober 2014
}

tugas fungsi merupakan satu kesatuan bagaikan mata uang, peran merupakan suatu perilaku atau tindakan dari seseorang atau sekelompok orang dalam melaksanakan tugas dan fungsinya.

Dilihat dari waktunya, dahulu pertahanan sipil yang lebih menitik beratkan pada membantu pertahanan dan keamanan, sedangkan kini sudah berubah kelembagaannya yaitu menjadi perlindungan masyarakat yang menitik beratkan pada perlindungan kepada masyarakat dari kebencanaan dan ketidak tertiban serta ketenteraman, dengan adanya perbedaan waktu tersebut kiranya kejelasan peran sangat diutamakan, dengan adanya kejelasan peran, posisi, jabatan maupun status sosial seseorang maupun sekelompok orang akan dapat menghindari adanya konflik kepentingan, dengan adanya kejelasan peran, posisi, jabatan maupun status sosial maka akan sekaligus mencerminkan hak dan kewajiban seseorang maupun sekelompok orang.

Namun apa yang akan terjadi jika peran, posisi, jabatan maupun status seseorang atau sekelompok orang tidak jelas, maka akan menimbulkan konflik terhadap peran itu sendiri, sebagaimana dikemukakan oleh Albernethy dan Stoelwinder (1995) dalam Puspa dan Rianto (1999) ${ }^{3}$ menemukan bahwa tingkat peran dipengaruhi oleh seberapa jauh para profesional ingin mempertahankan sikap keprofesionalan mereka dalam perusahaan dan seberapa jauh lingkungan pengendalian yang berlaku di perusahaan mengancam otonomi para profesional tersebut.

Tugas dan fungsi inilah yang ingin dibahas dalam kajian ini, selama ini mungkin kita telah terlena dengan peran Satlinmas selama ini, peran Satlinmas selama perlu diketahui terlebih dahulu pemahaman peran Satlinmas saat ini dengan peran Satlinmas dijaman terdahulu, dari kelembagaannya saja sudah berbeda, dahulu Pertahanan Sipil yang lebih menitik beratkan pada membantu pertahanan dan keamanan, sedangkan kini sudah berubah kelembagaannya yaitu menjadi Perlindungan Masyarakat yang menitik beratkan pada perlindungan kepada masyarakat dari kebencanaan dan ketidak tertiban serta ketenteraman.

Selanjutnya masih dalam literatur yang sama juga dijelaskan oleh Khan (1964) dalam Agustina (2009), teori peran (role theory) ${ }^{4}$ merupakan penekanan sifat individual sebagai pelaku sosial yang mempelajari perilaku yang sesuai dengan posisi yang ditempati di masyarakat, dalam hal ini yang dimaksudkan dengan teori tersebut adalah sifat individual sebagai seorang anggota Satlinmas dapat

\footnotetext{
3

https://www.google.com/?gws_rd=ssl\#q=teori+peran +puspa+dan+rianto+1999 diunduh tanggal 2

Desember 2014

${ }^{4}$ https://www.google.com/?gws_rd=ssl\#q=teori+pera $\underline{n+p u s p a+d a n+r i a n t o+1999}$ diunduh tanggal 2

Desember 2014
} 
melaksanakan dan menyesuaikan peranya dimasyarakat.

Peran yang selama ini diemban oleh Satuan Perlindungan Masyarakat telah dirumuskan dalam definisi Permendagri maupun peraturan lainnya, dengan berdasarkan berbagai definisi peran Satlinmas yang ada, adalah warga masyarakat yang disiapkan dan dibekali pengetahuan serta keterampilan untuk melaksanakan kegiatan penanganan bencana guna mengurangi dan memperkecil akibat bencana, serta ikut memelihara keamanan, ketentraman dan ketertiban masyarakat, kegiatan sosial kemasyarakatan.

Dalam melaksanakan tugas dan fungsinya anggota Satlinmas dapat saja terjadi konplik dilapangan, jika tugas dan fungsi tersebut tidak dapat dipahami oleh anggota, terjadinya konflik kepentingan yang diakibatkan belum adanya kejelasan tugas dan fungsi sebagaimana juga dikemukakan oleh Puspa dan Riyanto (1999) mengemukakan bahwa konflik terjadi karena tenaga kerja profesional memiliki norma dan sistem nilai yang diperolehnya dalam proses pendidikan berbenturan dengan norma, aturan, dan sistem nilai yang berlaku di perusahaan tempatnya bekerja.

Kemudian juga diperkuat oleh ${ }^{6}$ Menurut Hall (2004) dalam Rahman et al. (2007), kejelasan peran dianggap sebagai titik awal dari pemberdayaan psikologis dari individu. Individu yang tidak memiliki tanggung jawab yang jelas dan tidak tahu bagaimana untuk mencapai hal tersebut, maka mereka cenderung tidak mempercayai bahwa mereka memiliki keterampilan yang dibutuhkan dan kemampuan untuk mengerjakan sebuah tugas dengan layak atau merasa kurang diberdayakan

Masyarakat yang menjadi fokus utama dalam bagian ini, sebelum melanjutkan kepada hal yang lainnya, maka sebaiknya kita ketahui terlebih dahulu beberapa difinisi masyarakat menurut Pramuda ${ }^{7}$ Masyarakat (yang diterjemahkan dari istilah society) adalah sekelompok orang yang membentuk sebuah sistem semi tertutup atau sebaliknya, dimana kebanyakan interaksi adalah antara individu-individu yang terdapat dalam kelompok tersebut. Kata masyarakat berakar dari bahasa Arab, musyarakah. Arti yang lebih luasnya, sebuah masyarakat adalah suatu jaringan hubungan-hubungan antar entitasentitas. Masyarakat adalah sebuah kelompok atau komunitas yang interdependen atau individu yang saling bergantung antara yang satu dengan lainnya.

Kajian terkait dengan Peran Linmas disampaikan oleh Badan Perencana Pembangunan

\footnotetext{
5https://www.google.com/?gws_rd=ssl\#q=teori+pera

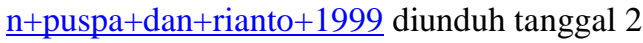
Desember 2014

${ }_{7}^{6}$ ibid
}

http://sosialsosiologi.blogspot.com/2012/12/definisimasyarakat.html diunduh tanggal 12 Desember 2014
Daerah Surakarta dengan judul Review Design Optimalisasi Peran Linmas Kota Surakarta sebagai berikut: Linmas di Kota Surakarta juga kurang dilibatkan dalam bidang tata kehidupan di masyarakat. Bahkan dalam Peraturan Walikota Nomor 7 Tahun 2010 Tentang Pertahanan Sipil Kota Surakarta Linmas terkesan hanya berfungsi dalam hal penanggulangan bencana alam dan keamanan. Fungsi perlindungan dalam bidang lain belum tersentuh secara nyata.

Sesungguhnya Kota Surakarta mempunyai banyak program yang saat ini sedang dijalankan. Anggaran yang telah dialokasikan oleh Pemerintah Kota Surakarta melalui APBD sebesar lebih dari 5 Milyard yang meliputi anggaran pengadaan personil, pengadaan alat sarana dan prasarana, pengadaan seragam dan honor. Akan tetapi besarnya anggaran tidak sesuai dengan tugas pokok dan fungsi yang seharus dilaksanakan, pola struktur komando dan struktur perintah serta organisasi masih belum jelas sampai pada tingkat kelurahan sehingga diperlukan analisa atau kajian untuk efektifitas pola komando yang seharusnya. ${ }^{8}$

Peran Linmas juga disampaikan berdasarkan hasil kajian Kepala Kesatuan Bangsa Politik dan Perlindungan Masyarakat mengatakan bahwa penyelenggaraan perlindungan masyarakat merupakan urusan wajib yang menjadi kewenangan pemerintah daerah provinsi, kabupaten dan kota, sebagaimana diamanatkan dalam Undang-Undang Nomor 32 Tahun 2004 Tentang Pemerintah Daerah khususnya dalam penjelasan Pasal 13 dan 14 ayat 1 sehingga program perlindungan masyarakat perlu terus diberdayakan dan ditingkatkan perannya dalam kehidupan sehari-hari, terutama di dalam menunjang program pemerintah dalam kegiatan sosial kemasyarakatan, penggulangan bencana, serta ikut memelihara ketentraman dan ketertiban umum baik dalam kegiatan sehari-hari maupun upaya bela negara. ${ }^{9}$

Penelitian dari Badan Penelitian dan Pengembangan Kementerian Dalam Negeri pada Tahun $2012{ }^{10}$ Studi Identifikasi Profil Satuan Polisi Pamong Praja, tujuan penelitian mengetahui profil kelembagaan, ketatalaksanaan, sumber daya manusia, dan sumber daya lainnya, hasil penelitian yang terkait dengan kelembagaan bidang perlindungan masyarakat menunjukan bahwa masih banyak Satpol PP di lokasi sampel belum

\footnotetext{
8

http://bappeda.surakarta.go.id/sites/default/files/DO KUMEN\%20KAJIAN\%20LINMAS\%202011.pdf diunduh tanggal 03 November 2014

http://www.jombangkab.go.id/index.php/web/entry/li nmas-sangat-dibutuhkan-untuk-keterentramanlingkungan.html diunduh tanggal 18 November 2014

${ }^{10}$ Gunawan dkk (2012) Studi Identifikasi Profil Satuan Polisi Pamong Praja.Litbang Kemendagri
} 
mamasukan struktur perlindungan masyarakat di organisasinya.

Kajian dari Badan Penelitian dan Pengembangan Kementerian Dalam Negeri pada Tahun 2013 oleh ${ }^{11}$ dengan judul Eksistensi Satuan Perlindungan Masyarakat, kajian ini bertujuan untuk menelaah secara historis dan filosofis tentang eksistensi Satuan Perlindungan Masyarakat dalam kontek kekinian, dalam kajian menunjukan keberadaan Satuan Perlindungan Masyarakat masih meninggalkan banyak persoalan diantaranya, pertama, mengenai dasar hukum pembentukan Satuan Perlindungan Masyarakat sampai kini, belum ada regulasi baru yang mengatur Satuan Perlindungan Masyarakat. Regulasi yang ada sudah terlalu uzur dan tidak bisa menangkap perkembangan zaman. Kedua rumusan konsep dan tugas pokok dan fungsi Satlinmas tumpang tindih dengan institusi lain. Ketiga, citra satlinmas di masyarakat semakin memudar dan cenderung dilecehkan, Keempat penggabungan Satuan Perlindungan Masyarakat ke dalam Polisi Pamong Praja dianggap tidak tepat, kerana beda filosofi. Penelitian ini bertujuan untuk Mengetahui sejauhmana satuan perlindungan masyarakat dalam melaksanakan perannya.

\section{METODE}

Penelitian ini adalah dengan menggunakan pendekatan penelitian kualitatif, penelitian ini menggunakan metode analisis deskriptif. Hal ini dimaksudkan untuk memberikan gambaran dan analisa yang lebih jelas mengenai peran Satuan Perlindungan Masyarakat (Satlinmas). Pertimbangan ilmiah penggunaan jenis penelitian kualitatif ialah untuk mendapatkan gambaran dan fenomena yang terjadi pada saat sekarang yang jelas terkait dengan fakta-fakta, dan gejala-gejala dari obyek penelitian yang ditemukan di lapangan secara realistiskomprehensif.

Pemulihan lokasi penelitian ini Kabupaten Cilacap, Kabupaten Cilacap telah mengamanatkan Peraturan Pemerintah Nomor 6 Tahun 2010 Tentang Satuan Polisi Pamong Praja (Satpol PP) bahwa unsur Perlindungan Masyarakat telah dimasukan kedalam struktur kelembagaannya Kantor Satuan Polisi Pamong Praja dan cukup berhasil dalam melaksanakan peran dalam menegakan Peraturan Daerah. Kabupaten Cilacap menjadi yang terbaik Indonesia sehingga menjadi acuan bagi daerah lain dalam pelaksanaan penegakan perda, Melalui hasil persidangan di pengadilan dan Tindakan Pidana Ringan Satuan Polisi Pamong Praja dan PPNS Kabupaten Cilacap telah menjadi Aset Penerimaan Daerah. Kabupaten Cilacap Satpol PP Cilacap kembali menjadi rujukan bagi peningkatan sumber daya dan kinerja dari Satpol PP daerah lain di

\footnotetext{
${ }^{11}$ Moh. Ilham A. Hamudy dkk (2013) Eksistensi Satuan Perlindungan Masyarakat, Litbang Kemendagri
}

Indonesia. Melalui kegiatan bimtek latihan bersama teknis operasional penegakan peraturan daerah serta persidangan bagi satuan polisi pamong praja, dan penyidik pegawai negeri sipil pada satuan kerja perangkat daerah provinsi.

\section{HASIL DAN PEMBAHASAN}

\section{Tugas dan fungsi Satinmas}

Regulasi yang berkenaan dengan keberadaan Satlinmas di Kabupaten Cilacap, yaitu Peraturan Bupati Cilacap Nomor 59 Tahun 2011 Tentang Pedoman Prosedur Tetap Operasional Pemberdayaan Satuan Perlindungan Masyarakat (Satlinmas), Peraturan Bupati tersebut telah mengacu kepada Undang-Undang 32 Tahun 2004 tentang Pemerintah Daerah dan Undang-Undang Nomor 24 Tahun 2007 Tentang Penanggulangan Bencana, khususnya pada Pasal 4 Huruf a Pasal 6 huruf b dan Pasal 8 Huruf b menyebutkan bahwa, tanggung jawab pemerintah dalam penyelenggaraan penaggulangan bencana meliputi perlindungan masyarakat dari dampak bencana serta Peraturan Daerah Kabupaten Cilacap Nomor 14 Tahun 2010 Tentang Organisasi dan Tata Kerja Lembaga Teknis Daerah dan Satuan Polisi Pamong Praja Kabupaten Cilacap.

Peraturan Daerah Kabupaten Cilacap Nomor 14 Tahun 2010 Tentang Organisasi dan Tata Kerja Lembaga Teknis Daerah dan Satuan Polisi Pamong Praja telah mengatur tentang organisasi dan tata kerja anggota satuan perlindungan masyarakat menjadi bagian dalam struktuktur Satpol PP, kemudian didalam Peraturan Bupati Cilacap Nomor 59 Tahun 2011 Tentang Pedoman Prosedur Tetap Operasional Pemberdayaan Satuan Perlindungan Masyarakat (Satlinmas), membagi kedalam 3 (tiga) kelompok besar yaitu satlinmas kabupaten, satlinmas kecamatan dan satlinmas desa/kelurahan. Masingmasing kelompok besar tersebut memiliki ciri dan karakteristik yang berbeda-beda, dari mulai tugas dan fungsinya sampai kepada penganggaran serta pembinaannya, untuk itu pada bagian selanjutnya akan digambarkan keterlibatan Satlinmas sebagai berikut.

Tugas dan fungsi satlinmas Kabupaten Cilacap sebagaimana tertuang dalam Peraturan Menteri Dalam Negeri Nomor 10 Tahun 2009 Tentang Penugasan Satuan Perlindungan Masyarakat dalam Penanganan Ketenteraman, Ketertiban, dan Keamanan Penyelenggaraan Pemilihan Umum selain itu juga mengacu pada Peraturan Menteri Dalam Negeri (Permendagri) Nomor 8 Tahun 2012 tentang Kewaspadaan Dini Masyarakat di Daerah yang pada intinya adalah melaksanakan dan membantu tugas dan fungsi Satuan Polisi Pamong Praja, khususnya dalam menanggulangan bencana baik sebelum terjadi bencana, pada saat bencana dan pada pasca bencana kemudian perlu juga merujuk kepada peraturan bupati tersebut juga sangat tepat dengan Surat Keputusan Menteri Dalam Negeri Nomor 131 Tahun 
2003 tentang Pedoman Penanggulangan Bencana dan Penanganan Pengungsi di Daerah. Pada Pasal 1 Huruf d dijelaskan bahwa penanggulangan bencana dan penanganan pengungsi di wilayah desa/kelurahan mulai dari dari tahap sebelum, pada saat terjadi bencana dan sesudah terjadi bencana atau pengungsian

Pada saat penanganan bencana ini anggota satlinmas dimasukan dalam tim Badan Penanganan Bencana Daerah (BPBD) Kabupaten Cilacap, anggota linmas satgas Rakyat Terlatih Cepat (RTC) diberi tugas oleh BPBD untuk piket di BPBD, keterlibatan Satgas Linmas RTC dalam penanggulangan bencana ikut berperan aktif khususnya pada tingkat kabupaten, ikut membantu dalam pengamanan situasi dan kondisi pada saat terjadi bencana.

Keteribatan satlinmas atau sering juga disebut satuan tugas (satgas) linmas Rakyat Terlatih Cepat (RTC) dalam fase kebencanaan seperti, fase pra bencana, di dalam fase ini satgas linmas RTC dilibatkan dalam persiapan dan sosialisasi penanganan kebencanaan, kemudian dalam fase bencana atau evakuasi kebencanaan, satgas linmas RTC dilibatkan dalam membantu Kepolisian dan Satuan Polisi Pamong Praja untuk memberikan pengamanan, ketentraman, dan ketertiban kepada warga dari lokasi bencana sampai kepada tempat pengungsian, selanjutnya pada fase berikutnya fase pemulihan atau rehabilistasi bencana peran Satgas Linmas RTC cukup bagus karena selain untuk memberikan pengamanan, fungsi linmas RTC berperan untuk memberikan bantuan tenaganya pada perbaikan sarana dan prasarana sesuai dengan keahlian yang dimiliki, pada fase Pemulihan inilah Satuan Tugas Linmas RTC mendapat tambahan selain honor yang didapat sebesar Rp. 580,000,mendapat juga honor penghasilan sebagai tukang batu, tukang kayu dalam proses rehabilitasi saran dan prasarana.

Keseluruhan anggota RTC pada Tahun 2014 selama bulan November sebanyak 36 anggota, direkrut dari masyarakat yang berkeinginan dan secara suka rela untuk mengabdi kepada daerah atau wilayahnya, keanggotaan satgas linmas RTC dipilih berdasarkan uji kompetensi dan penseleksian yang ketat, sehingga untuk menjadi linmas RTC tidaklah mudah, salah satu dari ke 36 anggota linmas RTC tersebut terdapat mantan petinju nasional berasal dari Kabupaten Cilacap.

Pembentukan peleton linmas RTC di Kabupaten Cilacap diupayakan untuk meningkatkan peran linmas dalam memberikan rasa aman terhadap tamu-tamu pemerintah yang berkunjung di Kabupaten Cilacap dan membantu aparat pemerintah dalam pengamanan penyelenggaraan kegiatan pemerintah di Kabupaten Cilacap.

Peleton linmas RTC diberi tugas untuk memberikan rasa aman terhadap tamu-tamu pemerintah yang berkunjung di Kabupaten Cilacap dalam kegiatan pemerintahan, dan membantu penanganan penanggulangan bencana alam di wilayah Kabupaten Cilacap serta membantu pengamanan penyelenggaraaan kegiatan pemerintah di wilayah Kabupaten Cilacap dan melaksanakan tugas-tugas harian yang diperintahkan oleh Kepala Satuan Polisi Pamong Praja.

Pada dasarnya anggota peleton Rakyat Terlatih Cepat (RTC) ini dibentuk untuk membeck Up Satuan Polisi Pamong Praja, maka yang terjadi adalah setiap ada kegiatan dalam bentuk pengamanan, ketenteraman dan ketertiban wilayah Kabupaten Cilacap, sedapat mungkin melibatkan dan mendayagunakan anggota satgas linmas RTC, dengan dilibatkannya anggota satgas linmas RTC dalam kegiatan membantu satpol pp akan memperoleh selain honor akan memperoleh uang tambahan bagi anggota yang ikut dalam kegiatan dimaksud. dengan masing-masing besaran berbedabeda setiap kegiatan berkisar antara Rp 50.000,sampai dengan Rp. 100.000,--

Penganggaran satlinmas, pemerintah telah menganggarkan kebutuhan anggota linmas RTC dari mulai pakaian sampai kepada honor yang diterima setiap bulannya, selain itu Uniform anggota Linmas RTC tidak berbeda dengan uniform yang digunakan anggota linmas pada umumnya yang berada di pemerintahan Kabupaten Cilacap, Linmas di kabupaten Cilacap dapat di kelompok menjadi dua yaitu Linmas yang memiliki Nomor Induk Pegawai (NIP) dan anggota Linmas yang tidak memiliki NIP, kedua-duanya dianggarkan dalam Anggaran Pendapatan Belanja Daerah (APBD) Kabupaten Cilacap.

Penganggaran yang dimaksud digunakan kedalam sturktur anggaran belanja rutin, untuk besaran gaji maupun honor diberikan disesuaikan dengan golongan dan kepangkatan dan jabatan yang diemban, kemudian untuk honor bagi anggota linmas RTC diberikan sebulan masing-masing sebesar Rp 480.000,- ditambah dengan uang makan sebesar Rp.100.000,- sehingga hampir dipastikan setiap anggota linmas RTC mendapat honor plus uang makan sebesar Rp. 580.000,--

Setiap anggota linmas RTC menerima honor plus uang makan sebesar Rp 580.000,- dirasakan masih belum cukup, terlebih bagi anggota yang memiliki keluarga besar sangat dirasakan kurang mencukupi, untuk itu pemerintah Kabupaten Cilacap memberikan kebebasan selain menjadi linmas RTC juga dipersilakan bekerja di tempat lain, seperti bekerja sebagai Satpam Pabrik dan sebagian bekerja di pabrik, selain itu juga satgas linmas RTC dilibatkan dalam acara-acara yang diselenggarakan oleh pemerintah daerah.

Anggota satgas linmas RTC dan satlinmas yang berada di kelurahan dan desa saat ini sudah tidak dapat lagi menerima bantuan modal usaha sebesar Rp. 2.000.000,- dan uang tali asih sebagai penghargaan pemerintah terhadap anggota satlinmas 
yang telah habis masa baktinya sebesar Rp. 1.000.000,- dan santunan kematian sebesar Rp. 2.000.000,- sejak Tahun 2012 sudah tidak lagi menerima bantuan tersebut setelah dikeluarkannya Peraturan Menteri Dalam Negeri Republik Indonesia Nomor 39 Tahun 2012 Tentang Perubahan Atas Peraturan Menteri Dalam Negeri Nomor 32 Tahun 2011 Tentang Pedoman Pemberian Hibah dan Bantuan Sosial yang bersumber dari Anggaran Pendapatan dan Belanja Daerah.

Sejatinya bantuan tersebut sangat dibutuhkan oleh anggota satlinmas baik yang berada di kabupaten maupun yang berada di kelurahan dan desa. Besar nilai tersebut memang sangat kecil tapi bagi kalangan orang kecil nilai tersebut sangat berarti untuk membantu anggota Satlinmas.

Pembinaan yang dilakukan terhadap anggota linmas RTC ini sangat proaktif, karena anggota linmas RTC ini mengadakan pertemuan sedikitnya sekali dalam sebulan, hal ini disesuaikan dengan waktu kegiatan yang akan dilaksanakan, dan pelatihan olah fisik dilakukan seminggu sekali yaitu kegiatan beladiri. Selain olah fisik dalam bentuk pelatihan beladiri juga diberikan pelatihan Pasukan Huru Hara (PHH) dan Pelatihan yang dilakukan oleh Badan Penanggulangan Bencana Daerah Kabupaten Cilacap.

Kondisi linmas RTC sangat berbeda dengan kondisi linmas yang berada di tingkat kelurahan maupun desa, berbeda dari jumlah maupun tingkat pendidikannya dan kesejahteraannya, bila jumlah anggota satgas linmas RTC hanya 36 anggota sedangkan jumlah anggota satlinmas di Kabupaten Cilacap berkisar antara 8.026 anggota yang tersebar di 24 kecamatan dan 284 kelurahan/desa, selain jumlah Satlinmas dan linmas RTC jauh berbeda, juga diikuti dengan perbedaan kualitas anggota Satgas Linmas RTC dan Satlinmas Kelurahan/Desa. Hal tersebut dijelaskan pada Tabel 1.
14 Tahun 2010 Tentang Organisasi dan Tata Kerja Lembaga Teknis Daerah dan Satuan Polisi Pamong Praja Kabupaten Cilacap serta Peraturan Bupati Cilacap Nomor 59 Tahun 2011 Tentang Pedoman Prosedur tetap Operasional Pemberdayaan Satuan Perlindungan Masyarakat (Satlinmas).

Peraturan Bupati Nomor 59 Tahun 2011 juga mengatur hal yang sama tentang Satuan Perlindungan Masyarakat dari satlinmas kabupaten, kecamatan dan sampai pada tingkat kelurahan/desa, pada bagian ini hanya akan membahas satlinmas yang berada di tingkat kelurahan dari mulai regulasi, tugas dan fungsi, penganggaran serta pembinaannya.

Regulasi yang digunakan untuk membahas pada bagian ini adalah regulasi yang berkenaan dengan kedudukan Satlinmas yang berada di tingkat kelurahan, regulasi yang digunakan sama saja yang digunakan regulasi kabupaten cilacap, yaitu Peraturan Daerah Kabupaten Cilacap Nomor 14 Tahun 2010 Tentang Organisasi dan Tata Kerja Lembaga Teknis Daerah dan Satuan Polisi Pamong Praja Kabupaten Cilacap serta Peraturan Bupati Cilacap Nomor 59 Tahun 2011 Tentang Pedoman Prosedur tetap Operasional Pemberdayaan Satuan Perlindungan Masyarakat (Satlinmas).

Regulasi yang terdapat di Peraturan Daerah Kabupaten Cilacap Nomor 14 Tahun 2010 Tentang Organisasi dan Tata Kerja Lembaga Teknis Daerah dan Satuan Polisi Pamong Praja Kabupaten Cilacap serta Peraturan Bupati Cilacap Nomor 59 Tahun 2011 tentang Pedoman Prosedur tetap Operasional Pemberdayaan Satuan Perlindungan Masyarakat (Satlinmas), khususnya untuk Kabupaten Cilacap, anggota satlinmasnya atau hansipnya tidak akan berpengaruh terhadap keberadaan dan kedudukan satlinmas/satuan hansip pada tingkat kelurahan dan desa dan keberadaan linmas atau hansip pada tingkat desa tidak berpengaruh terhadap adanya pencabutan Keputusan Presiden Nomor 55 Tahun 1972 Tentang

\section{Tabel 1. Perbedaan antara satgas linmas Rakyat Terlatih Cepat}

dan Anggota Satlinmas di Kelurahan/Desa

\begin{tabular}{clcc}
\hline No. & Keterangan & $\begin{array}{c}\text { Satgas Linmas RTC } \\
\text { Kabupaten }\end{array}$ & Anggota Satlinmas Kelurahan/Desa \\
\hline 1 & Jumlah & 36 Satgas & 8.026 anggota \\
2 & Honor & Rp. $480.000+$ Rp. & 100.000 \\
3 & Pendidikan & SLTP-SLTA & Rp.20.000 \\
4 & Usia rata & Dibawah 50 Tahun & SD-SLTP \\
\hline
\end{tabular}

Sumber: Data Primer diolah

Mempertimbangkan perbedaaan dari sisi yang berbeda namun jika melihat dari sisi aturan aturan dan kebijakan yang digunakan kurang lebih sama seperti Peraturan Daerah Kabupaten Cilacap Nomor
Penjempurnaan Organisasi Pertahanan Sipil Dan Organisasi Perlawanan Dan Keamanan Rakjat Dalam Rangka Penertiban Pelaksanaan Sistim Hankamrata, keberadaan Linmas atau Hansip akan selalu ada di 
hati rakyat khususnya warga kelurahan Kebon Manis akan tetap ada.

Berdasarkan anggaran APBD Kabupaten Cilacap untuk setiap satlinmas ditetapkan memperoleh honor sebesar Rp. 20.000 per bulan, bisa dibayangkan uang sebesar itu hanya cukup untuk beli rokok dan beli kopi saja dalam sehari sudah habis, untuk itu anggota menutupi kekurangannya melakukan pekerjaan dengan bekerja di pabrik-pabrik sebagai buruh ataupun security, selain itu ada juga yang berdagang, dan pengayuh becak.

Anggota Satlinmas mendapat tambahan penghasilan sesuai dengan pakaiannya adalah ketika anggota Satlinmas aktif di sosial kemasyarakatan, dalam bentuk pekerjaannya melakukan penjagaan keamanan, ketenteraman dan ketertiban pada saat masyarakat mempunyai acara hajatan, ataupun keagamaan.

Penunjukan pemberian tugas untuk membantu masyarakat yang memiliki acara dalam pengamanan, yaitu dengan dilakukan secara berjenjang, seperti pemohon atau warga yang akan melakukan hajat meminta ijin kepada pihak Kelurahan Kebon Manis meminta anggota satlinmas sebanyak 2 personil, kemudian dari pihak Kelurahan menseleksi anggota salinmas yang ditugasi berdasarkan area wilayahnya pemohon dan satlinmas berdekatan.

Pemberian honor atau apapun nama sejenisnya (ada yang memberi nama istilahnya dengan uang rokok atau uang makan), besaran uang pemberian tersebut pihak kelurahan tidak menargetkan jumlahnya, namun kisarannya antara Rp. 50.000,- sampai dengan Rp. 150.000,disesuaikan dengan tingkat ekonomi yang membutuhkannya dan diberikan secara langsung kepada anggota Satlinmas yang bertugas.

Pembinaan yang dilakukan pemerintah daerah terhadap anggota Satlinmas Kelurahan Kebon Manis yang berjumlah 21 anggota sejak Tahun 2005 tidak pernah mendapat pelatihan apapun dari Kabupaten, Kecamatan dan Kelurahan, namun untuk Kepala urusan Trantib Kelurahan Kebon Manis sudah pernah diikutkan dalam pelatihan gerak jalan.

Keanggotaan Satuan Perlindungan

Masyarakat (Satlinmas) yang terdaftar di Kelurahan Sebanyak 21 orang, dengan komposisi keanggota didominasi oleh anggota yang telah berumur 50 Tahun ke atas sedangkan untuk dibawah umur dibawah 50 Tahun hanya terdiri dari 4 anggota, dengan kondisi yang demikian itu maka ketika diadakan kumpul sesama anggota Satlinmas di tingkat kecamatan maupun kabupaten hanya separuh saja yang dapat hadir.

Pembinaan terhadap anggota Satlinmas dalam pemberian santunan dan pemberian modal serta tali asih baik di kabupaten dan kelurahan/desa, sejak 2012 anggota sudah tidak lagi menerimanya, hal ini yang menjadi sebuah pertanyaan besar bagi anggota yang mengira dana tersebut digunakan oleh kelurahan/desa sehingga ada rasa tidak percaya lagi terhadap kelurahan/desa.

Tidak menerimanya bantuan bagi anggota satlinmas dalam bentuk bantuan modal dan santunan serta tali asih sejak adanya Peraturan Menteri Dalam Negeri Republik Indonesia Nomor 39 Tahun 2012 Tentang Perubahan Atas Peraturan Menteri Dalam Negeri Nomor 32 Tahun 2011 Tentang Pedoman Pemberian Hibah dan Bantuan Sosial yang Bersumber dari Anggaran Pendapatan dan Belanja Daerah.

\section{Warga Masyarakat Dibekali Pengetahuan Dan Keterampilan}

Difinisi yang terkandung dalam Peraturan Menteri Dalam Negeri dijelaskan bahwa satlinmas adalah warga masyarakat disiapkan dan dibekali pengetahuan dan keterampilan untuk melaksanakan tugas dan fungsinya, hal itu dapat diartikan bahwa setiap anggota Satlinmas harus memiliki pengetahuan dan keterampilan tentang tugas dan fungsinya, namun bilamana terdapat anggota satlinmas yang belum pernah mendapatkan pengetahuan dan keterampilan tentang tugas dan fungsinya, maka dapat dipastikan orang tersebut bukan lagi menjadi anggota satlinmas melainkan hanya masyarakat biasa saja, walaupun anggota tersebut hanya tercatat di kelurahan/desa.

Kabupaten Cilacap membentuk satlinmas RTC berjumlah 36 anggota yang telah terlatih mendapatkan pengetahuan dan keterampilan, sedangkan jumlah anggota Satlinmas secara keseluruhan berjumlah 8.026 anggota Satlinmas, pada Tahun 2014 Kabupaten Cilacap, anggota Satlinmas mendapatkan pendidikan dan pelatihan kelinmasan berjumlah 713 anggota, dan pelaksana diklat dari Provinsi Jawa Tengah dan Kabupaten Cilacap, dengan melibatkan unsur pimpinan dan anggota satlinmas kelurahan dan desa, dengan jumlah tersebut dengan asumsi bahwa dalam setahun anggota satlinmas sebanyak 713, maka dibutuhkan waktu sekitar 12 tahun untuk memberikan pengetahuan dan keterampilan kepada seluruh keanggotaan satlinmas.

Hasil perhitungan diatas maka pertanyaannya apakah waktu yang cukup panjang itu dapat dijangkau dan bagaimana dengan anggota Satlinmas yang belum mendapat pengetahuan dan keterampilan, mengingat difinisi satlinmas adalah warga masyarakat yang diberi pengetahuan dan keterampilan untuk melaksanakan tugas-tugasnya.

Belum pernah atau tidak pernah anggota Satlinmas mendapat pembekalan dan pemberian pengetahuan dan keterampilan tentang tugas-tugas yang menjadi tanggungjawabnya itu sama saja dengan warga masyarakat biasa, walaupun secara yuridis anggota tersebut menggunakan pakaian dan atribut Satlinmas, namun faktanya anggota tersebut adalah warga masyarakat biasa. 


\section{Penanggulangan Bencana}

Bencana dapat diakibatkan oleh alam, maupun bencana akibat ulah manusia yang dapat menimbulkan korban jiwa dan harta benda serta kerusakan alam dan lingkungan, sedangkan salah satu penting satlinmas adalah ikut melakukan segala usaha dan kegiatan melindungi dan menyelematkan masyarakat terhadap bencana sehingga dapat membatasi/memperkecil jatuhnya korban serta mengurangi penderitaan masyarakat

Terkait hal itu, pemberdayaan Satlinmas dalam penanggulangan masyarakat dalam hal kebencanaan sudah dicanangkan oleh Kementerian Dalam Negeri, melalui Surat Edaran Menteri Dalam Negeri No 362/4396/SJ tanggal 11 Desember 2009 Tentang Pemberdayaan Satuan Perlindungan Masyarakat dalam Membantu Kegiatan Penanggulangan Bencana Banjir dan Tanah Longsor menyampaikan kepada para gubernur, dan bupati/walikota yang wilayahnya rawan bencana agar memerintahkan satuan kerja perangkat daerah (SKPD) terdapat perlindungan masyarakat untuk memberdayakan aparat Satlinmas dalam membantu program dimaksud.

Atas dasar Surat Edaran Menteri Dalam Negeri No 362/4396/SJ tanggal 11 Desember 2009 Tentang Pemberdayaan Satuan Perlindungan Masyarakat dalam Membantu Kegiatan Penanggulangan Bencana Banjir dan Tanah Longsor, Pemerintah Daerah Kabupaten Cilacap telah membentuk satgas RTC dalam tim Badan Penanganan Bencana Daerah (BPBD) Kabupaten Cilacap, dalam susunan tim tersebut anggota linmas Satgas RTC diberi tugas oleh BPBD dalam penanggulangan bencana ikut berperan aktif khususnya pada tingkat Kabupaten, dan ikut membantu dalam pengamanan situasi dan kondisi pada saat terjadi bencana.

Anggota Satlinmas yang memiliki peran khusus sering juga disebut Satuan Tugas (Satgas) Linmas Rakyat Terlatih Cepat (RTC), dalam kebencanaan seperti pada fase pra bencana, didalam fase ini satgas linmas RTC dilibatkan dalam persiapan dan sosialisasi penanganan kebencanaan, piket penjagaan di Obyek vital Kebupaten dan BPBD.

Kemudian dalam fase bencana atau tanggap darurat, satgas linmas RTC dilibatkan dalam membantu pengerahan pasukan untuk membantu evakuasi korban dan harta korban bencana dan membantu menyiapkan tenda penampungan sementara dan penyiapan infrastruktur vital sementara, dibawah arahan/komando BPBD, selanjutnya fase pasca bencana Satgas Linmas RTC diposisikan untuk membantu distribusi bantuan makanan dan material untuk korban bencana dan membantu upaya rehabilitasi dan rekonstruksi pasca bencana.

Dalam fase pasca bencana Satgas Linmas RTC berperan untuk memberikan bantuan tenaganya pada perbaikan sarana dan prasarana sesuai dengan keahlian yang dimiliki, pada fase pasca bencana inilah Satuan Tugas Linmas RTC mendapat tambahan penghasilan sebagai tukang batu, tukang kayu dalam proses rehabilitasi sarana dan prasarana.

Pada dasarnya anggota peleton Rakyat Terlatih Cepat (RTC) ini dibentuk untuk mendukung Satuan Polisi Pamong Praja, maka yang terjadi adalah setiap ada kegiatan dalam bentuk pengamanan, ketenteraman dan ketertiban wilayah Kabupaten Cilacap, menurut Kepala Bidang Perlindungan Masyarakat Cilacap Kabupaten sedapat mungkin diupayakan untuk melibatkan dan mendayagunakan anggota satgas linmas RTC dalam membantu Satpol PP.

Tugas Satlinmas dalam penanganan bencana guna mengurangi dan memperkecil akibat bencana, dan anggota Satlinmas dapat berperan dan andil dalam fase sebelum terjadi bencana yaitu: ikut bersama-sama dengan Badan Penanggulangan Bencana Daerah dan pemerintah daerah dalam stimulasi bencana, sosialisasi kebencanaan, serta turut aktif dalam proses pengevakuasi warga dan menjaga ketenteraman dan ketertiban di penampungan, kemudian pada saat rehabilitasi daerah yang terkena bencana seperti ikut membangun rumah warga dan membangun kembali fasilitas desa.

Kegiatan-kegiatan satlinmas dalam penanganan bencana guna mengurangi dan memperkecil akibat bencana, serta ikut memelihara keamanan, ketentraman, dan ketertiban masyarakat, kegiatan sosial kemasyarakatan untuk di tingkat Kabupaten Cilacap sudah berjalan cukup baik karena sudah didukung dengan peraturan daerah dan peraturan bupati.

Selain di dukung dengan peraturan, anggota satlinmas di Kabupaten Cilacap dalam melaksanakan perannya, juga didukung dengan kualitas yaitu anggotanya sudah dibekali dengan pembinaan untuk memiliki kemampuan dan keterampilan dalam melaksnaakan tugas-tugasnya.

Keberadaan satgas linmas RTC di tingkat Kabupaten Cilacap dalam memberdayakan anggotanya selain jumlahnya terbatas juga pemberian honor yang sangat minim, namun begitu segala upaya yang telah dilakukan pemerintah daerah Kabupaten Cilacap untuk memberdayakan dan mendayagunakan anggota satlinmasnya sudah cukup baik. Seperti mengikut sertakan kegaitan-kegiatan yang dilaksanaan Satuan Polisi Pamong Praja untuk mengajak Satuan perlindungan masyarakat RTC.

Sedangkan Satgas Linmas Kabupaten Cilacap hanya sebagai pendukung dalam melaksanakan kebencanaan membantu tugas dari Badan Penanganan Bencana Daerah dan membantu penyelenggaraan ketenteraman dan ketertiban umum unit Satpol PP Kabupaten Cilacap. 


\section{Keamanan, Ketenteraman, Dan Ketertiban}

Berbagai regulasi yang ada urusan keamanan menjadi urusan pemerintah secara absolut, dari sudut pandang Undang-Undang, Peraturan Pemerintah bahkan sampai kepada Permendagri.

Berikut Peraturan Menteri Dalam Negeri yang mendifinisikan Satuan Perlindungan Masyarakat melekatkan peran keamanan, dapat dilihat pada Tabel 2.
Peran satlinmas yang menjadi tugas dan fungsi dalam regulasi yang berbenturan dengan regulasi sebelumnya merupakan konflik, sebagaimana dikemukakan oleh Puspa dan Riyanto (1999) mengemukakan bahwa konflik terjadi karena tenaga kerja profesional memiliki norma dan sistem nilai yang diperolehnya dalam proses pendidikan berbenturan dengan norma, aturan, dan sistem nilai yang berlaku di perusahaan tempatnya bekerja.

Tabel 2: Bidang Keamanan yang Terdapat dalam Permendagri

\begin{tabular}{llc}
\hline NO & \multicolumn{1}{c}{ REGULASI } & BAB, PASAL \\
\hline 1 & Keputusan Menteri Dalam & Bab II \\
& Negeri Nomor: 1 Tahun 1977 & Kedudukan, \\
& Tentang Susunan Organisasi & Tugas Pokok \\
& Dan Tata Kerja Pertahanan & Dan Fungsi \\
& Sipil Di Daerah & Pasal 3
\end{tabular}

DIFINISI SATLINMAS

Pertahanan Sipil mempunyai tugas

merencanakan, mempersiapkan dan menyusun serta mengerahkan potensi Rakyat dalam bidang perlindungan masyarakat (LINMAS) untuk mengurangi /memperkecil akibat-akibat bencana perang/bencana alam serta mempertinggi Ketahanan Nasional pada umumnya dan garis depan yang kokoh kuat pada khususnya untuk membantu dan memperkuat pelaksanaan Pertahanan Keamanan Rakyat

2 Keputusan Menteri Dalam Negeri Nomor 131 Tahun 2003 Tentang Pedoman Penanggulangan Bencana Dan Penanganan Pengungsi Di Daerah Menteri Dalam Negeri

\section{Lampiran \\ Satuan Pertahanan Sipil/Perlindungan} Kepmendagri 131

Masyarakat yang selanjutnya disebut Satuan Hansip/Linmas adalah organisasi masyarakat yang berada di Desa/Kelurahan, yang disiapkan dan dibekali pengetahuan serta ketrampilan untuk melaksanakan kegiatan penanggulangan bencana dan penanganan pengungsi guna mengurangi dan memperkecil akibat bencana.

\section{Peraturan Menteri Dalam}

Negeri Nomor 12 tahun 2006

Tentang Kewaspadaan Dini

Masyarakat Di Daerah

\section{Bab I Ketentuan Umum} selanjutnya disebut Satlinmas adalah bentuk
Satuan Perlindungan Masyarakat yang pengorganisasian masyarakat yang disiapkan dan disusun serta dibekali pengetahuan dan keterampilan di bidang perlindungan masyarakat yang difasilitasi oleh pemerintah atau pemerintah daerah.

\begin{tabular}{|c|c|c|c|}
\hline 4 & $\begin{array}{l}\text { Peraturan Menteri Dalam } \\
\text { Negeri Nomor } 62 \text { Tahun } 2008 \\
\text { Tentang Standar Pelayanan } \\
\text { Minimal Bidang Pemerintahan } \\
\text { Dalam Negeri Di } \\
\text { Kabupaten/Kota }\end{array}$ & $\begin{array}{c}\text { Lampiran: } \\
\text { pengertian } \\
\text { Linmas }\end{array}$ & $\begin{array}{l}\text { Petugas Perlindungan Masyarakat (Linmas) } \\
\text { merupakan satuan yang memiliki tugas umum } \\
\text { pemeliharaan ketentraman dan ketertiban } \\
\text { masyarakat. Satuan ini memiliki peran penting } \\
\text { dalam ketertiban masyarakat secara luas. } \\
\text { (Landasan hukum keberadaan Linmas: Surat } \\
\text { Keputusan Wakil Menteri I urusan Pertahanan } \\
\text { Keamanan Nomor MI/72/1962 yang } \\
\text { dikeluarkan pada 29 April 1962) }\end{array}$ \\
\hline 5 & $\begin{array}{l}\text { Peraturan Menteri Dalam } \\
\text { Negeri Nomor: } 10 \text { Tahun } \\
\text { 2009Tentang Penugasan Satuan } \\
\text { Perlindungan Masyarakat } \\
\text { Dalam Penanganan } \\
\text { Ketenteraman, Ketertiban, Dan } \\
\text { Keamanan Penyelenggaraan } \\
\text { Pemilihan Umum }\end{array}$ & $\begin{array}{c}\text { BAB I } \\
\text { Ketentuan } \\
\text { Umum }\end{array}$ & $\begin{array}{l}\text { Satuan Perlindungan Masyarakat yang } \\
\text { selanjutnya disebut Satuan Linmas adalah } \\
\text { warga masyarakat yang disiapkan dan dibekali } \\
\text { pengetahuan serta keterampilan untuk } \\
\text { melaksanakan kegiatan penanganan bencana } \\
\text { guna mengurangi dan memperkecil akibat } \\
\text { bencana, serta ikut memelihara keamanan, } \\
\text { ketentraman dan ketertiban masyarakat, } \\
\text { kegiatan sosial kemasyarakatan. }\end{array}$ \\
\hline
\end{tabular}




\begin{tabular}{|c|c|c|c|}
\hline 6 & $\begin{array}{l}\text { Peraturan Menteri Dalam } \\
\text { Negeri Nomor } 44 \text { Tahun } 2010 \\
\text { Tentang Ketentraman, } \\
\text { Ketertiban Dan Perlindungan } \\
\text { Masyarakat Dalam Rangka } \\
\text { Penegakan Hak Asasi Manusia }\end{array}$ & $\begin{array}{c}\text { BAB I } \\
\text { Ketentuan } \\
\text { umum ayat } 10\end{array}$ & $\begin{array}{l}\text { Satuan Perlindungan } \text { Masyarakat yang } \\
\text { selanjutnya disebut Satuan Perlindungan } \\
\text { Masyarakat adalah Warga masyarakat yang } \\
\text { disiapkan dan dibekali pengetahuan serta } \\
\text { ketrampilan untuk melaksanakan kegiatan } \\
\text { penanganan bencana guna mengurangi dan } \\
\text { memperkecil akibat bencana, serta ikut } \\
\text { memelihara keamanan, ketentraman dan } \\
\text { ketertiban masyarakat, kegiatan sosial } \\
\text { kemasyarakatan. }\end{array}$ \\
\hline 7 & 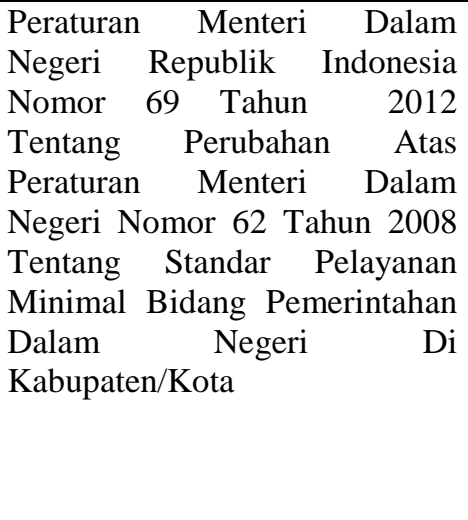 & Lampiran 2 & $\begin{array}{l}\text { Pengertian Satuan perlindungan masyarakat } \\
\text { yang selanjutnya disebut satuan linmas adalah } \\
\text { warga masyarakat yang disiapkan dan dibekali } \\
\text { pengetahuan serta ketrampilan untuk membantu } \\
\text { pelaksanaan kegiatan penanganan bencana guna } \\
\text { mengurangi dan memperkecil akibat bencana, } \\
\text { serta ikut membantu memelihara keamanan, } \\
\text { ketentraman, ketertiban masyarakat dan } \\
\text { kegiatan sosial kemasyarakatan sebagaimana } \\
\text { dimaksud dalam Peraturan Menteri Dalam } \\
\text { Negeri Nomor } 44 \text { Tahun } 2010 \text { tentang } \\
\text { Ketentraman dan Perlindungan Masyarakat } \\
\text { Dalam Rangka Penegakan Hak Asasi Manusia. }\end{array}$ \\
\hline 8 & $\begin{array}{l}\text { Menteri Dalam Negeri } \\
\text { Republik Indonesia Peraturan } \\
\text { Menteri Dalam Negeri } \\
\text { Republik Indonesia Nomor } 84 \\
\text { Tahun } 2014 \text { Tentang } \\
\text { Penyelenggaraan Perlindungan } \\
\text { Masyarakat }\end{array}$ & $\begin{array}{c}\text { BAB I } \\
\text { Ketentuan } \\
\text { Umum ayat (3) }\end{array}$ & $\begin{array}{l}\text { Satuan Perlindungan Masyarakat yang } \\
\text { selanjutnya disebut Satlinmas adalah Organisasi } \\
\text { yang dibentuk oleh pemerintah Desa/Kelurahan } \\
\text { dan beranggotakan warga masyarakat yang } \\
\text { disiapkan dan dibekali pengetahuan serta } \\
\text { keterampilan untuk melaksanakan kegiatan } \\
\text { penanganan bencana guna mengurangi dan } \\
\text { memperkecil akibat bencana, serta ikut } \\
\text { memelihara keamanan, ketenteraman dan } \\
\text { ketertiban masyarakat, kegiatan sosial } \\
\text { kemasyarakatan. }\end{array}$ \\
\hline
\end{tabular}

Sumber: Data sekunder diolah

Kemudian juga diperkuat oleh Hall (2004) dalam Rahman et al. (2007) , kejelasan peran dianggap sebagai titik awal dari pemberdayaan psikologis dari individu. Individu yang tidak memiliki tanggung jawab yang jelas dan tidak tahu bagaimana untuk mencapai hal tersebut, maka mereka cenderung tidak mempercayai bahwa mereka memiliki keterampilan yang dibutuhkan dan kemampuan untuk mengerjakan sebuah tugas dengan layak atau merasa kurang diberdayakan.

Bersamaan dengan hal tersebut diatas bahwa, dengan adanya ketidakjelasan peran yang menjadi tanggungjawab sebagai anggota satlinmas, maka satlinmas secara otomatis tidak mengetahui dan mengerti apa yang menjadi tanggungjawabnya dan sekaligus akan terjadi konplik antara kelembagaan, untuk itu perlunya ada kejelasan peran didalam mendifinisikannya. Seperti yang telah diatur dalam kebijakan pemerintah dalam Peraturan Menteri Dalam Negeri tentang satlinmas kiranya peran keamanan harus diperjelas dan dipertegas.

Uraian diatas dimaksudkan adalah pemerintah daerah untuk tidak melaksanakan urusan keamanan sebab keamanan sudah menjadi urusannya pemerintah pusat secara absolut, karena didalam pelayanan dasar tidak lagi menyebutkan keamanan tetapi ketenteraman, ketertiban dan perlindungan masyarakat.

Di dalam peraturan tersebut tidak memisahkan satlinmas kecamatan ataupun satlinmas kelurahan/desa. peraturan tersebut menjelaskan secara umum, untuk itu satlinmas itu berlaku di Indonesia.

\section{KESIMPULAN}

Peran Satuan Perlindungan Masyarakat (Satlinmas) dalam penanganan bencana, menjaga keamanan, ketenteraman dan ketertiban pada umumnya untuk di Kabupaten Cilacap hanya terbatas pada membantu lembaga yang melaksanakan penanganan bencana, keamanan, ketenteraman masyarakat dan ketertiban umum.

Adanya keterbatasan jangkauan pelayanan kepada masyarakat dari lembaga yang menangani penanggulangan bencana, keamanan, ketenteraman dan ketertiban hanya pada tingkat kecamatan. 
Pelayanan penanggulangan bencana, keamanan, ketenteraman dan ketertiban kepada masyarakat pada tingkat RT dan RW secara langsung, cepat dan tepat belum dilaksanakan dengan optimal

Untuk dapat membantu lembaga yang menangani penanggulangan bencana, keamanan, ketenteraman dan ketertiban secara langsung, cepat dan tepat sampai kepada tingkat RT dan RW, kiranya Kementerian Dalam Negeri melalui Direktorat Jenderal Pemerintahan Umum melalui Surat Edaran atau Keputusan Menteri Dalam Negeri tentang Pembentukan Unit Satlinmas di Tingkat Rukun Warga yang bertugas melaksanakan penanggulangan bencana, keamanan, ketenteraman dan ketertiban secara langsung, cepat dan tepat bersifat darurat.

Kemampuan anggota Satlinmas perlu ditingkatkan melalui pendidikan dan pelatihan yang sesuai dengan bidang tugasnya.

\section{Daftar Pustaka}

Gunawan dkk (2012). Studi Identifikasi Profil Satuan Polisi Pamong Praja.Litbang Kemendagri

http://artikata.com/arti-347254-redefinisi.html diunduh tanggal 21 Oktober 2014

http://mustaqiim.wordpress.com/2011/04/10/redefinisidari-makna-ke-praktek/ diunduh tanggal 21 Oktober 2014

http://kbbi.web.id/fungsi diunduh tanggal 24 Oktober 2014

https://www.google.com/?gws_rd=ssl\#q=teori+peran+p uspa+dan+rianto+1999 diunduh tanggal 2 Desember 2014

http://sosialsosiologi.blogspot.com/2012/12/definisimasyarakat.html diunduh tanggal 12 Desember 2014

https://www.google.com/?gws_rd=ssl\#q=teori+sosiolog i diunduh tanggal 2 Desember 2014

http://bappeda.surakarta.go.id/sites/default/files/DOKU MEN\%20KAJIAN\%20LINMAS\%202011.pdf diunduh tanggal 03 November 2014

http://www.jombangkab.go.id/index.php/web/entry/lin mas-sangat-dibutuhkan-untuk-keterentraman- lingkungan.html diunduh tanggal 18 November 2014

http://sosialsosiologi.blogspot.com/2012/12/definisimasyarakat.html diunduh tanggal 12 Desember 2014

https://www.google.com/?gws_rd=ssl\#q=teori+sosiolog i diunduh tanggal 2 Desember 2014

Moh. Ilham Hamudy, dkk (2013) Eksistensi Satuan Perlindungan Masyarakat. Litbang Kemendagri

Keppres No 55 Tahun 1972 tentang Penyempurnaan Organisasi Pertahanan Sipil dan Organisasi Perlawanan Rakyat (Wanra) dan Keamanan Rakyat (Kamra) dalam rangka penertiban pelaksanaan sistem pertahanan keamanan rakyat

Keputusan Presiden Republik Indonesia Nomor 56 Tahun 1972 tentang Penyerahan Pembinaan Organisasi Pertahanan Sipil Dari Departemen Pertahanan Keamanan Kepada Departemen Dalam Negeri

Peraturan Menteri Dalam Negeri Nomor 69 Tahun 2012 tentang Perubahan Peraturan Menteri Dalam Negeri Nomor 62 Tahun 2008 Standart Pelayanan Minimal Bidang Pemerintahan Dalam Negeri Kabupaten/Kota

Peraturan Pemerintah 38 Tahun 2007 tentang Pembagian Urusan

Permendagri Nomor 69 Tahun 2012 tentang perubahan atas Permendagri no 62 Tahun 2008 tentang Standart Pelayanan Minimal (SPM) Pemerintahan Dalam Negeri Kabupaten Kota

Peraturan Pemerintah Nomor 38 Tahun 2007 tentang Pembagian Urusan Pemerintahan

Undang-Undang Nomor 3 Tahun 2002 Tentang Pertahanan Negara

Undang-Undang Nomor 2 Tahun 2002 tentang Kepolisian Republik Indonesia

Undang-Undang 23 Tahun 2014 tentang Pemeriintahan Daerah

Undang-undang 23 Tahun 2014 tentang Pemerintahan Daerah

Undang-Undang 23 Tahun 2014 tentang Pemeriintahan Daerah

Undang-Undang Nomor 3 Tahun 2002 Tentang Pertahanan Negara

Undang-Undang Nomor 2 Tahun 2002 tentang Kepolisian Republik Indonesia 
